\title{
Prevalence of Toxoplasma gondii in retail fresh meat products from free-range chickens in Spain
}

\author{
María Jesús Gracia Salinas ${ }^{\bowtie}$, Cristina Escolano Campos, \\ María Paz Peris Peris, Nabil Halaihel Kassab \\ Instituto Agroalimentario de Aragón - IA2 (Universidad de Zaragoza - CITA), Veterinary Faculty, 50013 Zaragoza, Spain \\ mjgracia@unizar.es
}

Received: March 14, $2021 \quad$ Accepted: September 15, 2021

\begin{abstract}
Introduction: Toxoplasma gondii is one of the most prevalent zoonotic protozoan parasites worldwide and affects the vast majority of warm-blooded animal species, including humans. Postnatal infection in humans occurs through the ingestion of sporulated $T$. gondii oocysts or via the oral intake of parasite tissue cysts during the consumption of raw or undercooked meat. In this regard, given their high exposure to oocysts, chickens (Gallus domesticus) raised on the ground constitute a potential source of $T$. gondii. Material and Methods: For the first time in Spain, a survey was undertaken in commercial retail free-range poultry. A total of 50 thighs from different animals were analysed. The samples were homogenised and an acid pepsin digestion procedure was applied prior to molecular analysis. Toxoplasma gondii DNA was isolated from meat by qPCR. Two sets of primers were used for DNA amplification targeting the specific sequence of a 529 bp repeat element and another set of primers was utilised for the surface antigen protein-1 gene. Results: DNA extracted from 5 out of 50 tissue samples was positive for both genes by qPCR amplification. Conclusion: The 10\% prevalence of Toxoplasma infection found in commercial free-range chickens raises public health issues.
\end{abstract}

Keywords: Toxoplasma gondii, free-range chickens, Spain, meat, qPCR.

\section{Introduction}

Toxoplasmosis is a zoonosis caused by the protozoan Toxoplasma gondii affecting mammals and birds worldwide (24). Human infection occurs primarily as a result of the ingestion of undercooked meat containing tissue cysts or through consumption of food or water polluted with faeces of felids carrying $T$. gondii oocysts. Food-borne transmission of Toxoplasma is regarded as one of the main channels for the infection of humans (19), and risk factor studies point at the intake of undercooked or raw meat as an important route for human $T$. gondii infection in Europe $(6,15)$.

One of the most important hosts of $T$. gondii is believed to be chickens. In this aspect, the type of husbandry practised is linked with the prevalence of parasite infection $(7,28)$. In chickens, recent articles summarising worldwide $T$. gondii occurrence indicate that seroprevalences ranged between $0 \%$ and $100 \%$ with higher prevalence in free-range/backyard chickens $(7$, 12, 27, 28). Chickens are habitually exposed to $T$. gondii, notably when they range freely, and therefore could harbour great numbers of this parasite although they rarely become sick from Toxoplasma infection $(7,26)$. They arguably play a significant role in the epidemiology of $T$. gondii in rural areas, and could be even more relevant than rodents in this sense $(3,7,8$, 25). Free-range chickens are regarded as sensitive indicators for environmental contamination, given that they feed from the ground and in so doing are more vulnerable to infection with $T$. gondii oocysts. In fact, they have been employed as sentinels on farms for monitoring of possible contamination by this parasite $(8$, $18,26)$. It should also be pointed out that as generally with raw or undercooked meat, chicken meat constitutes another relevant source of infection for humans when it is consumed or managed with poor hygiene $(4,13,26)$.

Regarding the disease burden of toxoplasmosis (expressed in quality- or disability-adjusted life years), $T$. gondii is one of the most important food-borne pathogens (20). As meat seems to be a key source of infections by $T$. gondii in Europe, studies should determine the 
incidence of infectious tissue cysts in primary livestock species (19). In this regard, the detection of antibodies appears to be a useful method to assess the extent of parasitisation by $T$. gondii in poultry. However, serological screening cannot be used for testing individual animals to declare their meat $T$. gondii-free (19). Identifying the presence of $T$. gondii in poultry meat could contribute to the recognition of potential health risks concerning $T$. gondii infections in humans.

In recent years, several studies have been conducted to detect the prevalence of $T$. gondii infection in chicken meat $(5,14,21,22,30)$. However, although chicken is one of the most-consumed meats in Spain (17), no studies have been carried out to evaluate the presence of $T$. gondii in chicken meat products in the country. This lack of information makes it difficult to evaluate the risk to consumers or to make meaningful health risk assessments, which is essential for the creation of food safety guidelines and policies. Therefore, to gain more insight into the role of poultry meat as a source of human infection with $T$. gondii, the objective of the present study was to investigate the prevalence of this parasite in retail meat of free-range chickens.

\section{Material and Methods}

Chicken meat sampling and sample preparation for analysis. From January 2015 to April 2015, 50 thighs from free-range chickens (Gallus domesticus) were purchased in different grocery stores in Zaragoza (northeastern Spain). Only meat labelled as having been produced in Spain was selected for analysis. The purchased meat samples were analysed at the Laboratory of Parasitology in the Faculty of Veterinary Medicine of the University of Zaragoza in Spain. The thighs were kept at $4{ }^{\circ} \mathrm{C}$ and stored for a maximum of 48 hours until processing. Thighs were cut into small pieces, minced, and homogenised. A total of $50 \mathrm{~g}$ from each sample was used and a concentration technique with an acid pepsin digestion procedure was applied, as described elsewhere (2). All samples were handled under the same conditions, and careful cleaning and disinfection of equipment was carried out between preparation of one sample and preparation of the next to avoid crosscontamination and false positives.

DNA extraction and identification of $T$. gondii by qPCR. Analysis of $T$. gondii DNA from meat was performed by qPCR. A $200 \mu \mathrm{L}$ volume of the concentrated samples was added to $300 \mu \mathrm{L}$ of lysis buffer and homogenated using a pestle with rotating plastic plungers in an Eppendorf tube. The DNA extraction was performed using an UltraClean Tissue \& Cells DNA Isolation Kit, catalogue no. 12334-S (Mo Bio Laboratories, Carlsbad, CA, USA) according to the manufacturer's instructions. Two sets of primers were used for DNA amplification, ToxoRoc and ToxoRepeat 500, targeting the specific sequence of a 529 bp repeat element, and another set of primers, ToxoSG1, was utilised for the surface antigen protein-1 gene (SAG1) as shown in Table 1. All primers were supplied by Integrated DNA Technologies (IDT).

A CFX Connect real-time PCR instrument (BioRad Laboratories, Hercules, CA, USA) was used for the detection and amplification of $T$. gondii using GoTaq SYBR Green Master Mix (catalogue no. A6002; Promega, Madison, WI, USA). The reaction volume was $20 \mu \mathrm{L}$, and samples were run in triplicate. The protocol used was as described elsewhere (11). Each PCR run included a negative control, a positive control, and a separate reaction for Actin DNA copies as an internal control (IC). A sample was considered positive if at least two of the triplicates were positive with both markers for the 529 bp repeat element, and the SAG1 marker served to confirm the result. The threshold cycle $(\mathrm{Ct})$ value used was indicated by the marker $529 \mathrm{bp}$ repeat element $(\mathrm{Ct}$ had to be lower than 38) as determined by a standard curve for the set of ToxoRoc primers, achieved using a serial logarithmic dilution of negative homogenate of chicken thigh spiked with a 10 -fold serial dilution of DNA from in vitro cultured $T$. gondii tachyzoite cells. Serial dilutions ranged from $10^{2}$ to $10^{6}$ copies of DNA/ $0.01 \mathrm{~mL}$. Average $\mathrm{Ct}$ were obtained from each dilution triplicate using the CFX real-time apparatus. Linear regression analysis of the $\mathrm{Ct}$ value (y axis) versus the $\log$ of the initial copy number present in each sample dilution ( $x$ axis) was calculated directly along with the primer set efficiency (E) by the CFX Master Manager 2.0 software for the apparatus.

\section{Results}

As expected, the sensitivities of both sets of primers, ToxoRoc and ToxoRepeat, for the 529 bp repeat element were similar and around two logs higher than that of the primer set for the SAG1 gene (data not shown). It is assumed that from 200 up to 300 repeats are expected in a $T$. gondii DNA genome. An efficiency of $97 \%$ was observed for the ToxoRoc primer (Fig. 1). Threshold cycle values from this primer set were used for the estimation of the number of amplicon/g of tissue.

Table 1. Primers utilised for the detection of T. gondii in this study

\begin{tabular}{|c|c|c|c|c|}
\hline Primer & Primer sequences & Gene & Length (nt) & Reference \\
\hline $\begin{array}{l}\text { ToxoRoc F } \\
\text { ToxoRoc R }\end{array}$ & $\begin{array}{l}\text { 5'-TAGACGAGACGACGCTTTCC-3' } \\
\text { 5'- TCGCCCTCTTCTCCACTCT-3' }\end{array}$ & $\begin{array}{l}\text { T. gondii repetitive } \\
\text { sequence }\end{array}$ & 64 & (11) \\
\hline $\begin{array}{l}\text { ToxoRepeat } 500 \mathrm{~F} \\
\text { ToxoRepeat } 500 \mathrm{R}\end{array}$ & $\begin{array}{l}\text { 5'-CGCTGCAGGGAGGAAGACGAAAGTTG-3' } \\
\text { 5'-CGCTGCAGACACAGTGCATCTGGATT-3' }\end{array}$ & $\begin{array}{l}\text { T. gondii repetitive } \\
\text { sequence }\end{array}$ & 529 & (11) \\
\hline $\begin{array}{l}\text { ToxoSG1 F } \\
\text { ToxoSG1 R } \\
\end{array}$ & $\begin{array}{l}\text { 5'-TCATCGGTCGTCAATAA-3' } \\
\text { 5'- CTTTGACTCCATCTTTCC-3' } \\
\end{array}$ & SAG1 & 123 & (11) \\
\hline
\end{tabular}

nt - nucleotide 
Table 2. Real-time positive PCR results for the chicken thigh samples used in this study

\begin{tabular}{cccc}
\hline $\begin{array}{c}\text { Positive } \\
\text { samples }\end{array}$ & $\begin{array}{c}\text { Average } \\
\mathrm{Ct}\end{array}$ & $\begin{array}{c}\text { Estimated number } \\
\text { of copies } T \text {. gondii }\end{array}$ & $\begin{array}{c}\text { SAG1 PCR } \\
\text { product** }\end{array}$ \\
\hline 1 & 35.30 & $2.1 / \mathrm{g}$ & positive \\
4 & 34.60 & $3.4 / \mathrm{g}$ & positive \\
14 & 36.16 & $1.1 / \mathrm{g}$ & positive \\
15 & 34.31 & $4.1 / \mathrm{g}$ & positive \\
20 & 35.71 & $1.6 / \mathrm{g}$ & positive \\
\hline
\end{tabular}

*Estimated copies based on 250 repeats of the 529 bp repeat DNA element of $T$. gondii

$* *$ PCR-specific fusion product at $82.5^{\circ} \mathrm{C}$

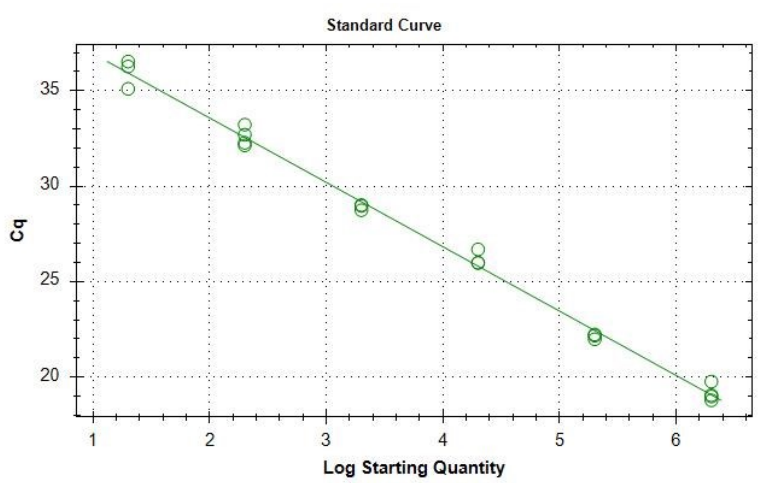

Fig. 1. Standard curve for ToxoRoc primers reacted with cultured T. gondii-spiked chicken thigh samples

\section{Discussion}

Regarding the prevalence of $T$. gondii in meat, our results do not differ significantly from those of a previous study carried out in eastern China (30), in which $8.17 \%$ of muscle tissue samples were positive in PCR for $T$. gondii. Lower prevalence was detected in Canada (3.9\%) (14) and in Scotland (4.8\%) (22) after investigation of retail meat by PCR. However, a higher prevalence was found by Chumpolbanchorn et al. (5) in Australia and by Pardini et al. (21) in Argentina, where respectively $44 \%(22 / 50)$ and $30.3 \%(10 / 33)$ of tissue samples analysed were positive by PCR.

The fact that the tissue analysed was the brain may be the cause for the higher prevalence found in the latter two studies. Toxoplasma gondii appears to prefer specific sites in chickens, as viable tissue cysts are found in varying numbers in particular organs or body parts. The brain and heart were clearly identified as predilection sites in chickens, with higher parasite loads and more frequent positivity compared to breast, thigh and drumstick muscle $(20,26,29)$. We sampled lower limb tissue (drumsticks), as it is the tissue often consumed by humans. It is likely that higher prevalence would be found in brain or heart samples. In naturally infected chickens, only 3 out of 24 birds of which heart samples were positive in magnetically captured RT PCR also provided positive drumstick samples (26).

The present study having detected $T$. gondii from these free-range chickens highlights the parasite as a public health concern. While the prevalence of $T$. gondii in chicken thighs is lower than in other tissues
$(8,19,26,29)$, the ingestion of this poultry muscle, just as ingestion of other poultry tissue, is still a potential route of infection in humans if it is undercooked. Despite meat being considered an important source of human exposure to $T$. gondii, chickens are not regarded as a high-risk vector, because typically their meat is well cooked (16). Nonetheless, specific recipes (such as chicken carpaccio, barbecued chicken or chicken sashimi) or products (sausages) call for procedures in which meat may not be heat treated sufficiently to inactivate the parasite (9).

Mouse and cat bioassays are the gold standards for detecting the presence of viable $T$. gondii in meat $(7,10$, 23). Nevertheless, bioassays are time consuming, expensive and present ethical considerations. The PCR assay is a specific, rapid, sensitive and cost-effective method for detecting T. gondii DNA in chickens (29). However, PCR methods may be inadequate for determining viable $T$. gondii, as they detect both viable and dead parasites in the samples, leading to unreliable results such as overestimation of the $T$. gondii infectivity in a meat sample (7). Rani and Pradhan (23) demonstrated that obtaining a sample positive for $T$. gondii is 1.96 times more likely by PCR than by the bioassay method. This experiment found DNA in the sample from both live and dead parasites, pointing at the existence of possible false positive results in PCR and thereby at frequent overestimation of the parasite content which is actually hazardous.

Detection of Toxoplasma in the current work was by qPCR. We have only demonstrated the presence of T. gondii DNA within our samples, and not the presence of viable parasites capable of initiating a human infection. It is possible that we have overestimated the parasitism. However, a recent study from Argentina carried out to detect and isolate viable $T$. gondii from tissues obtained from free-range chickens amplified DNA in 30.3\% (10/33) of samples analysed and isolated viable T. gondii parasites from $27.7 \%$ (5/18) (21). Therefore, very similar data are obtained applying the two different methodologies.

The encysted form of the parasite is noted for being quite hardy, surviving for weeks at temperatures as low as $1-4^{\circ} \mathrm{C}$, and only exhibiting a rapid decline of viability outside the temperature range of $-12^{\circ} \mathrm{C}$ to $67^{\circ} \mathrm{C}(1,10)$. Tissues analysed in the present study had not been subjected to any previous physicochemical treatments, and that it is probable that a significant amount of the T. gondii DNA detected in this study by qPCR would have corresponded to viable parasites.

Poultry meat is broadly consumed in Spain, but there is no legal requirement to examine it for $T$. gondii infection before it enters the market. Due to the relatively high prevalence rates observed, undercooked or not previously frozen meat from free-range chicken could represent a potential risk to the consumer. The implementation of good management measures on poultry farms is recommended to decrease the $T$. gondii infection in poultry. 
The lack of information in Spain on the prevalence of Toxoplasma infection in meat perceived before this study was surprising. To the authors' knowledge, this is the first study of $T$. gondii presence in retail chicken meat in Spain. The present study shows that $T$. gondii DNA has been detected in retail meat samples from freerange chickens, indicating that the consumption of meat from this species should be regarded as a potential risk of infection for humans in Spain.

Conflict of Interests Statement: The authors declare that there is no conflict of interests regarding the publication of this article.

Financial Disclosure Statement: Funding for the research and publication of this article was provided by the Government of Aragón and European Regional Development Fund (FEDER) (Grupo A17_17R grant RAySA: Reproducción Asistida y Sanidad Animal).

Animal Rights Statement: None required.

\section{References}

1. Alizadeh A.M., Jazaeri S., Shemshadi B., Hashempour-Baltork F., Sarlak Z., Pilevar Z., Hosseini H.: A review on inactivation methods of Toxoplasma gondii in foods. Pathog Glob Health 2018, 112, 306-319, doi: 10.1080/20477724.2018.1514137.

2. Bayarri S., Gracia M.J., Lázaro R., Pérez-Arquillué C., Barberá M., Herrera A.: Determination of the viability of Toxoplasma gondii in cured ham using bioassay: influence of technological processing and food safety implications. J Food Prot 2010, 73, 2239-2243, doi: 10.4315/0362-028X-73.12.2239.

3. Beltrame M.A.V., Pena H.F.J., Ton N.C., Lino A.J.B., Gennari S.M., Dubey J.P., Pereira F.E.L.: Seroprevalence and isolation of Toxoplasma gondii from free-range chickens from Espírito Santo state, southeastern Brazil. Vet Parasitol 2012, 188, 225-230, doi: 10.1016/j.vetpar.2012.03.053.

4. Casartelli-Alves L., Boechat V.C., Macedo-Couto R., Ferreira L.C., Nicolau J.L., Neves L.B., Millar P.R., Vicente R.T., Oliveira R.V.C., Muniz A.G., Bonna I.C.F., Amendoeira M.R.R., Silva R.C., Langoni H., Schubach T.M.P., Menezes R.C.: Sensitivity and specificity of serological tests, histopathology and immunohistochemistry for detection of Toxoplasma gondii infection in domestic chickens. Vet Parasitol 2014, 204, 346-351, doi: 10.1016/j.vetpar.2014.05.039.

5. Chumpolbanchorn K., Lymbery A.J., Pallant L.J., Pan S., Sukthana Y., Thompson R.C.A.: A high prevalence of Toxoplasma in Australian chickens. Vet Parasitol 2013, 196, 209-211, doi: 10.1016/j.vetpar.2013.01.009.

6. Cook A.J.C., Gilbert R.E., Buffolano W., Zufferey J., Petersen E., Jenum P.A., Foulon W., Semprini A.E.: Sources of Toxoplasma infection in pregnant women: European multicentre case-control study. Br Med J 2000, 321, 142-147, doi: 10.1136/bmj.321.7254.142.

7. Dubey J.P.: Toxoplasmosis of animals and humans (2nd ed.). CRC Press, Boca Raton, 2010, doi: 10.1201/9781420092370.

8. Dubey J.P., Lehman T., Lautner F., Kwok O.C.H., Gamble H.R.: Toxoplasmosis in sentinel chickens (Gallus domesticus) in New England farms: seroconversion, distribution of tissue cysts in brain, heart, and skeletal muscle by bioassay in mice and cats. Vet Parasitol 2015, 214, 55-58, doi: 10.1016/j.vetpar.2015.09.004.

9. Fabian B.T., Hedar F., Koethe M., Bangoura B., Maksimov P., Conraths F.J., Villena I., Aubert D., Seeber F., Schares G.: Fluorescent bead-based serological detection of Toxoplasma gondii infection in chickens. Parasite Vector 2020, 13, 388, doi: 10.1186/s13071-020-04244-6.

10. Franssen F., Gerard C., Cozma-Petruţ A., Vieira-Pinto M., Jambrak A.R., Rowan N., Paulsen P., Rozycki M., Tysnes K., Rodríguez-Lázaro D., Robertson L.: Inactivation of parasite transmission stages: Efficacy of treatments on food of animal origin. Trends Food Sci Technol 2019, 83, 114-128, doi: 10.1016/j.tifs.2018.11.009.

11. Gracia M.J., Lázaro R., Pérez-Arquillué C., Pagán R., Ramos S., García J.L., Bayarri S.: High-Pressure Processing (HPP) of raw and dry-cured ham from experimentally infected pigs as a potential tool for the risk control of Toxoplasma gondii. IFSET 2020, 61, 102315, doi: 10.1016/j.ifset.2020.102315.

12. Guo M., Dubey J.P., Hill D.E., Buchanan R.L., Gamble H.R., Jones J.L., Pradhan A.K.: Prevalence and risk factors for Toxoplasma gondii infection in meat animals and meat products destined for human consumption. J Food Prot 2015, 78, 457-476, doi: 10.4315/0362-028X.JFP-14-328.

13. Hill D.E., Dubey J.P.: Toxoplasma gondii prevalence in farm animals in the United States. Int J Parasitol 2013, 43, 107-113, doi: 10.1016/j.ijpara.2012.09.012.

14. Iqbal A., Janecko N., Pollari F., Dixon B.: Prevalence and molecular characterization of Toxoplasma gondii DNA in retail fresh meats in Canada. Food Waterborne Parasitol 2018, 13, e0003, doi: 10.1016/j.fawpar.2018.e00031.

15. Kapperud G., Jenum P.A., Stray-Pedersen B., Melby K.K., Eskild A., Eng J.: Risk factors for Toxoplasma gondii infection in pregnancy. Results of a prospective case-control study in Norway. Am J Epidemiol 1996, 144, 405-412, doi: 10.1093/oxfordjournals.aje.a008942.

16. Kijlstra A., Jongert E.: Control of the risk of human toxoplasmosis transmitted by meat. Int J Parasitol 2008, 38, 1359-1370, doi: 10.1016/j.ijpara.2008.06.002

17. Ministerio de Agricultura Pesca y Alimentación (MAPAMA). 2019. https://www.mapa.gob.es/eu/alimentacion/temas/consumotendencias/informe2019_vf_tcm35-540250.pdf (accesed: 10-092021).

18. Moré G., Maksimov P., Pardini L., Herrmann D.C., Bacigalupe D., Maksimov A, Basso W., Conraths F.J., Schares G., Venturini M.C. Toxoplasma gondii infection in sentinel and free-range chickens from Argentina. Vet Parasitol 2012, 184, 116-121, doi: 10.1016/j.vetpar.2011.09.012.

19. Opsteegh M., Schares G., Blaga R., van der Giessen J.: EFSA supporting publication EN-995: Experimental studies of Toxoplasma gondii in the main livestock species (GP/EFSA/BIOHAZ/2013/01). Final report. European Food Safety Agency, Parma, 2016.

20. Opsteegh M., Schares G., van der Giessen J.: EFSA supporting publication EN-996: Relationship between seroprevalence in the main livestock species and presence of Toxoplasma gondii in meat (GP/EFSA/BIOHAZ/2013/01): An extensive literature review. Final report. European Food Safety Agency, Parma, 2016.

21. Pardini L., Moré G., Rudzinski M., Gos M.L., Campero L.M., Meyer A., Bernstein M., Unzaga J.M., Venturini M.C.: Toxoplasma gondii isolates from chickens in an area with human toxoplasmic retinochoroiditis. Exp Parasitol 2016, 166, 16-20, doi: 10.1016/j.exppara.2016.03.006.

22. Plaza J., Dámek F., Villena I., Innes E.A., Katzer F., Hamilton C.M.: Detection of Toxoplasma gondii in retail meat samples in Scotland. Food Waterborne Parasitol 2020, 20, e00086, doi: 10.1016/j.fawpar.2020.e00086

23. Rani S., Pradhan A.K.: Evaluation and meta-analysis of test accuracy of direct PCR and bioassay methods for detecting Toxoplasma gondii in meat samples. LWT 2020, 131, 109666 , doi: 10.1016/j.lwt.2020.109666.

24. Robert-Gangneux F., Aubert D., Villena I.: Toxoplasmosis: A widespread zoonosis diversely affecting humans and animals. In: Zoonoses-Infections affecting humans and animals. Focus on Public Aspects, edited by A. Sing, Springer, Dordrecht, 2015, pp. 355-376, doi: 10.1007/978-94-017-9457-2 14. 
25. Schares G., Bangoura B., Randau F., Goroll T., Ludewig M., Maksimov P., Matzkeit B., Sens M., Bärwald A., Conraths F.J., Opsteegh M., Van der Giessen J.: High seroprevalence of Toxoplasma gondii and probability of detecting tissue cysts in backyard laying hens compared with hens from large free range farms. Int $\mathrm{J}$ Parasitol 2017, 47, 765-777, doi: 10.1016/j.ijpara.2017.07.003.

26. Schares G., Koethe M., Bangoura B., Geuthner A.C., Randau F., Ludewig M., Maksimov P., Sens M., Bärwald A., Conraths F.J., Villena I., Aubert D., Opsteegh M., Van der Giessen J.: Toxoplasma gondii infections in chickens - performance of various antibody detection techniques in serum and meat juice relative to bioassay and DNA detection methods. Int J Parasitol 2018, 48, 751-762, doi: 10.1016/j.ijpara.2018.03.007.

27. Shokri A., Sharif M., Teshnizi S.H., Sarvi S., Rahimi M.T., Mizani A., Ahmadpour E., Montazeri M., Daryani A.: Birds and poultries toxoplasmosis in Iran: A systematic review and meta- analysis. Asian Pac J Trop Med, 2017, 10, 635-642, doi: 10.1016/j.apjtm.2017.07.013

28. Stelzer S., Basso W., Silván J.B., Ortega-Mora L.M., Maksimov P., Gethmann J., Conraths F.J., Schares G.: Toxoplasma gondii infection and toxoplasmosis in farm animals: risk factors and economic impact. Food Waterborne Parasitol 2019, 12, e00037, doi: 10.1016/j.fawpar.2019.e00037

29. Yan C., Yue C.L., Yuan Z.G., Lin R.Q., He Y., Yin C.C., Xu M.J., Song H.Q., Zhu X.Q.: Molecular and serological diagnosis of Toxoplasma gondii infection in experimentally infected chickens. Vet Parasitol 2010, 173, 179-183, doi: 10.1016/j.vetpar. 2010.07.011.

30. Zou Y., Nie L.B., Zhang N.Z., Zou F.C., Zhu S.Q., Cong W.: First genetic characterization of Toxoplasma gondii infection in poultry meat intended for human consumption in eastern China. Infect Genet Evol 2017, 55, 172-174, doi: 10.1016/j.meegid. 2017.08.022. 